\title{
OPEN Anti-inflammatory effect of gold nanoparticles supported on metal oxides
}

\author{
Takashi Fujitaa ${ }^{1,2 \otimes}$, Maeva Zysman ${ }^{3,4,5}$, Dan Elgrabli ${ }^{3,6}$, Toru Murayama ${ }^{1}$, Masatake Haruta ${ }^{1}$, \\ Sophie Lanone ${ }^{3}$, Tamao Ishida ${ }^{1}$ \& Jorge Boczkowski ${ }^{3,7 凶}$
}

Gold (AU) can be deposited as nanoparticles (NPs) smaller than $10 \mathrm{~nm}$ in diameter on a variety of metal oxide (MOx) NPs. Au/MOx have high catalytic performance and selective oxidation capacity which could have implications in terms of biological activity, and more specifically in modulation of the inflammatory reaction. Therefore, the aim of this study was to examine the effect of $\mathrm{Au} / \mathrm{TiO}_{2}, \mathrm{Au} / \mathrm{ZrO}_{2}$ and $\mathrm{Au} / \mathrm{CeO}_{2}$ on viability, phagocytic capacity and inflammatory profile (TNF- $\alpha$ and IL- $1 \beta$ secretion) of murine macrophages. The most important result of this study is an anti-inflammatory effect of Au/ MOx depending on the MOx nature with particle internalization and no alteration of cell viability and phagocytosis. The effect was dependent on the MOx NPs chemical nature $\left(\mathrm{Au} / \mathrm{TiO}_{2}>\mathrm{Au} / \mathrm{ZrO}_{2}>\mathrm{Au} /\right.$ $\mathrm{CeO}_{2}$ if we consider the number of cytokines whose concentration was reduced by the NPs), and on the inflammatory mediator considered. The effect of $\mathrm{Au} / \mathrm{TiO}_{2} \mathrm{NPs}$ was not related to Au NPs size (at least in the case of $\mathrm{Au} / \mathrm{TiO}_{2} \mathrm{NPs}$ in the range of 3-8 nm). To the best of our knowledge, this is the first demonstration of an anti-inflammatory effect of Au/MOX.

Gold $(\mathrm{Au})$ can be deposited as nanoparticles (NPs) smaller than $10 \mathrm{~nm}$ in diameter on a variety of metal oxide (MOx) NPs (Au/MOx) (see Fig. S1 as an example). Au/MOx have attracted much attention due to their high catalytic performance for such as room temperature $\mathrm{CO}$ oxidation and selective oxidations in liquid phase ${ }^{1,2}$. The catalytic activity of $\mathrm{Au}$ strongly depends on the kind of support. For example, although $\mathrm{TiO}_{2}$ is almost inactive for $\mathrm{CO}$ oxidation, the deposition of $\mathrm{Au} \mathrm{NPs}_{\text {onto }} \mathrm{TiO}_{2}$ enables to catalyze CO oxidation at room temperature ${ }^{3,4}$. The selective oxidation of glucose by Au supported on activated carbon or metal oxides has been a very active research area, as the transformation of readily available glucose to valuable gluconic acid is of great importance ${ }^{5,6}$.

These data in the field of heterogeneous catalysis have firmly established that deposition of Au on MOx NPs increases dramatically the intrinsic catalytic activity and this could also be the case for the biological activity. For example, Menchon et al. ${ }^{7}$ reported that $\mathrm{Au} / \mathrm{CeO}_{2}$ exhibits antioxidant activity against reactive oxygen species (ROS) in Hep3B and HeLa cell related lines due to a peroxidase activity. Since the inflammatory reaction is highly dependent on oxidative stress ${ }^{8}$ one can hypothesize that, in addition to their antioxidant properties, Au/MOx can have anti-inflammatory effects. Such an effect could have important implications in terms of medical utilization of $\mathrm{Au} / \mathrm{MOx}$. However, to the best of our knowledge no data on this effect is available in the current literature.

Therefore, in the present study we examined the effect of $\mathrm{Au} / \mathrm{MOx}$ on cytotoxic and inflammatory response of macrophages, a key cell type involved in the inflammatory reaction. We used murine macrophages and investigated the roles of the size of Au NPs, the chemical nature of the supporting MOx NPs, and the kinetics of Au/ $\mathrm{MOx}$ interference with the inflammatory reaction.

\section{Results}

Physicochemical properties of Au/MOx. Physicochemical properties of $\mathrm{Au} / \mathrm{MOx}$ are summarized in Table 1. Sizes of primary particles of $\mathrm{MOx}\left(\mathrm{TiO}_{2}, \mathrm{ZrO}_{2}\right.$, and $\left.\mathrm{CeO}_{2}\right)$ were in the range of 7-26 nm but MOx NPs are generally agglomerated to form secondary micrometer-sized (2.4-9.4 $\mu \mathrm{m})$ particles. Actual gold loading amounts of $\mathrm{Au} / \mathrm{MOx}$ were ca. $1 \mathrm{wt} \%$ for all samples. The average sizes of $\mathrm{Au} \mathrm{NPs}$ on $\mathrm{TiO}_{2}$ and $\mathrm{ZrO}_{2}$ prepared by

\footnotetext{
${ }^{1}$ Department of Applied Chemistry for Environment, Graduate School of Urban Environmental Sciences, Tokyo Metropolitan University, 1-1Minami-osawa, Hachioji, Tokyo 192-0397, Japan. ${ }^{2}$ Department of Applied Chemistry, School of Engineering, Tokyo University of Technology, 1401-1 Katakura, Hachioji, Tokyo 192-0982, Japan. ${ }^{3}$ Univ Paris est Creteil, INSERM, IMRB, 94010 Creteil, France. ${ }^{4}$ Univ Bordeaux, Centre de Recherche Cardio-Thoracique de Bordeaux, U1045, CIC, 1401 Bordeaux, France. ${ }^{5}$ Service des Maladies Respiratoires, CHU Bordeaux, Bordeaux, France. ${ }^{6}$ SAS Naorlnnov, Courbevoie, France. ${ }^{7}$ AP-HP, Hopital Henri Mondor, Antenne de Pneumologie, 94010 Creteil, France. ${ }^{\bowtie}$ email: fujitatks@stf.teu.ac.jp; jorge.boczkowski@inserm.fr
} 


\begin{tabular}{|c|c|c|c|c|c|}
\hline & Specific surface area $/ \mathrm{m}^{2} / \mathrm{g}^{\mathrm{a}}$ & Primary particle size of metal oxide/ $/ \mathbf{n m}^{\mathrm{b}}$ & Secondary particle size of metal oxide $/ \mu \mathrm{m}^{\mathrm{c}}$ & Au loading $/ w \%^{d}$ & Au particle size $/ \mathrm{nm}^{\mathrm{e}}$ \\
\hline $\mathrm{Au} 3 / \mathrm{TiO}_{2}$ & 54 & 26 & 9.4 & 0.96 & $3.3 \pm 1.4$ \\
\hline $\mathrm{Au} 8 / \mathrm{TiO}_{2}$ & 54 & 26 & 9.4 & 1.18 & $7.8 \pm 2.7$ \\
\hline $\mathrm{Au} / \mathrm{ZrO}_{2}$ & 94 & 11 & 3.6 & 0.97 & $3.3 \pm 1.8$ \\
\hline $\mathrm{Au} / \mathrm{CeO}_{2}$ & 114 & 7.3 & 2.4 & 0.96 & No data ${ }^{\mathrm{f}}$ \\
\hline
\end{tabular}

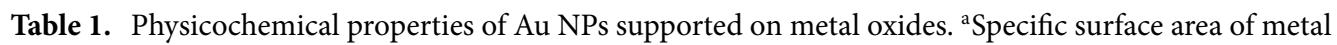
oxide was calculated from $\mathrm{N}_{2}$ adsorption isotherms using the Brunauer-Emmett-Teller (BET) method.

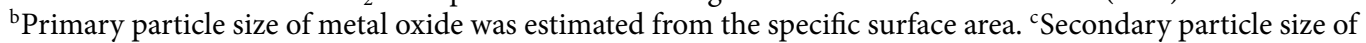
metal oxide after the deposition of Au NPs was measured by dynamic laser scattering. ${ }^{\mathrm{d}}$ Actual loading amount of Au was determined by inductively coupled plasma-atomic emission spectroscopy (ICP-AES) or atomic absorption spectrometry (AAS). ${ }^{\text {e}}$ Average particle size of Au NPs on metal oxides were estimated by HAADFSTEM. ${ }^{\mathrm{f}}$ Majority of Au species was considered to be atomically dispersed on $\mathrm{CeO}_{2}$ and could not be detected due to a limitation of resolution and low contrast between heavy Ce and Au atoms by TEM.

deposition-precipitation were both of $3.3 \mathrm{~nm}$. To examine the size effect of Au NPs, Au NPs with an average size of $8 \mathrm{~nm}$ were deposited on $\mathrm{TiO}_{2}$ by solid grinding. High-angle annular dark-field scanning transmission electron microscopic (HAADF-STEM) images of Au/MOx are shown in Fig. 1. For Au/ $\mathrm{TiO}_{2}$ and $\mathrm{Au} / \mathrm{ZrO}_{2}, \mathrm{Au}$ NPs were highly dispersed on $\mathrm{MOx}$ NPs. On $\mathrm{CeO}_{2}$, the most of Au species is atomically dispersed but only small amount Au NPs with ca. 20 in diameter was observed (Fig. 1d).

No cytotoxic effect of $\mathrm{Au} / \mathrm{TiO}_{2}$ NPs on mouse macrophages. Since $\mathrm{Au} / \mathrm{TiO}_{2}$ has been extensively studied in the field of catalysis ${ }^{1,3,4}$ we have first compared biological effects of $\mathrm{Au} / \mathrm{TiO}_{2}$ samples having different size of $\mathrm{Au}$ NPs versus $\mathrm{TiO}_{2}$ NPs on mouse peritoneal macrophages. Au NPs with two different mean diameters ( 3 and $8 \mathrm{~nm}$ ) supported on pristine $\mathrm{TiO}_{2} \mathrm{NPs}$ were termed $\mathrm{Au} 3 / \mathrm{TiO}_{2}$ and $\mathrm{Au} 8 / \mathrm{TiO}_{2}$, respectively. No cytotoxicity was observed by either 3-[4,5-dimethylthiazol-2-yl]-2,5 diphenyl tetrazolium bromide (MTT) or lactate dehydrogenase $(\mathrm{LDH})$ release assays for $\mathrm{TiO}_{2}$ and $\mathrm{Au} / \mathrm{TiO}_{2} \mathrm{NPs}$ regardless of the concentration $\left(1\right.$ to $100 \mu \mathrm{g} \mathrm{ml} \mathrm{m}^{-1}$ ), the exposure time ( 24 and $48 \mathrm{~h}$ ) and the size of Au NPs (Fig. 2).

In addition to cytotoxicity evaluation, we examined whether $\mathrm{Au} / \mathrm{TiO}_{2} \mathrm{NPs}$ modified the phagocytic capac-

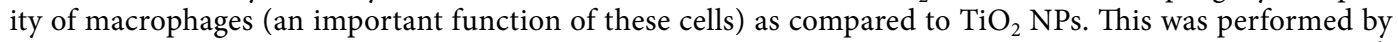
quantifying phagocytosis of fluorescent beads after cells incubation with $\mathrm{TiO}_{2}$ and $\mathrm{Au} / \mathrm{TiO}_{2} \mathrm{NPs}\left(50 \mu \mathrm{g} \mathrm{ml} l^{-1}\right.$, $6 \mathrm{~h}$ incubation). The results of these experiments showed both $\mathrm{TiO}_{2}$ and $\mathrm{Au} / \mathrm{TiO}_{2} \mathrm{NPs}$ significantly increased the phagocytosis of fluorescent beads by peritoneal macrophages, but the differences between $\mathrm{TiO}_{2}$ and $\mathrm{Au} /$ $\mathrm{TiO}_{2}$ was not observed. This result shows that Au NPs did not modulate phagocytic capacity of macrophages (an important function of these cells).

Macrophages incubation with $\mathrm{TiO}_{2}$ and $\mathrm{Au} / \mathrm{TiO}_{2} \mathrm{NPs}$ significantly and similarly increased the phagocytosis of fluorescent beads by peritoneal macrophages (Fig. S2).

$\mathrm{TiO}_{2}$ and $\mathrm{Au} / \mathrm{TiO}_{2} \mathrm{NPs}$ are internalized in mouse peritoneal macrophages. Cellular uptake and intracellular morphology upon $24 \mathrm{~h}$ exposure to $\mathrm{TiO}_{2}$ and $\mathrm{Au} / \mathrm{TiO}_{2} \mathrm{NPs}$ were investigated in ultra-thin sections of resin-embedded cells using TEM.

$\mathrm{TiO}_{2} \mathrm{NPs}_{\text {and } \mathrm{Au} / \mathrm{TiO}} \mathrm{NPs}\left(50 \mu \mathrm{g} \mathrm{ml}^{-1}\right)$ were internalized in cells. The prevalent localization of NPs agglomerates was observed in cell vacuoles (Fig. S3). In accordance with the previous paragraph showing a lack of cytotoxicity, no morphologic sign of cell damage was observed.

No inflammation induced by $\mathrm{Au} / \mathrm{TiO}_{2}$ NPs. Incubation of mouse peritoneal macrophages with $\mathrm{TiO}_{2}$ NPs $\left(50 \mu \mathrm{g} \mathrm{ml}^{-1}, 6 \mathrm{~h}\right)$, induced a significant increase in the concentration of TNF- $\alpha$ and IL- $1 \beta$, two main proinflammatory cytokines, in cell culture medium (Fig. 4). In contrast, the deposition of $\mathrm{Au} \mathrm{NPs}$ onto $\mathrm{TiO}_{2}$ greatly reduced the concentration of both TNF- $\alpha$ and IL- $1 \beta$ as compared to pristine $\mathrm{TiO}_{2}$, and this effect was independent on the size of Au NPs.

Au/TiO 2 NPs attenuate lipopolysaccharide (LPS)-induced inflammation. Having demonstrated that $\mathrm{Au} / \mathrm{TiO}_{2} \mathrm{NPs}$ did not elicit an inflammatory reaction, we questioned whether $\mathrm{Au} / \mathrm{TiO}_{2} \mathrm{NPs}$ could blunt inflammation induced in a model of pathophysiological relevance, such as macrophages exposure to Escherichia Coli LPS. Since no difference of anti-inflammatory effect was observed between $\mathrm{Au} 3 / \mathrm{TiO}_{2}$ and $\mathrm{Au} 8 / \mathrm{TiO}{ }_{2}$, we investigated the effects of $\mathrm{Au} 3 / \mathrm{TiO}_{2} \mathrm{NPs}$ (referred to as $\mathrm{Au} / \mathrm{TiO}_{2}$ in the following experiments). Mouse peritoneal macrophages were incubated with culture media for $6 \mathrm{~h}$ (control condition) or LPS for $2 \mathrm{~h}$, and then the following $4 \mathrm{~h}$ with LPS alone or LPS plus $\mathrm{TiO}_{2}$ or $\mathrm{Au} / \mathrm{TiO}_{2}$. Taking into account the results presented in the previous paragraph, TNF- $\alpha$ and IL- $1 \beta$ cell culture supernatant concentrations were measured as a surrogate of the inflammatory reaction. As expected, incubation of cells with LPS for $2+4 \mathrm{~h}$ induced a significant increase as compared to the control condition ( $\mathrm{p}<0.05$, Fig. 5a,b). Incubation of LPS followed by $\mathrm{TiO}_{2} \mathrm{NPs}_{\text {did not sig- }}$ nificantly modify the effect of LPS alone. By contrast, this last effect was significantly attenuated by macrophage incubation with $\mathrm{Au} / \mathrm{TiO}_{2} \mathrm{NPs}$ ( $\mathrm{p}<0.05$, Fig. 5a,b. These results show that $\mathrm{Au} / \mathrm{TiO}_{2}$ can attenuate LPS induced inflammation, even when cells are incubated with these NPs after incubation with LPS. 

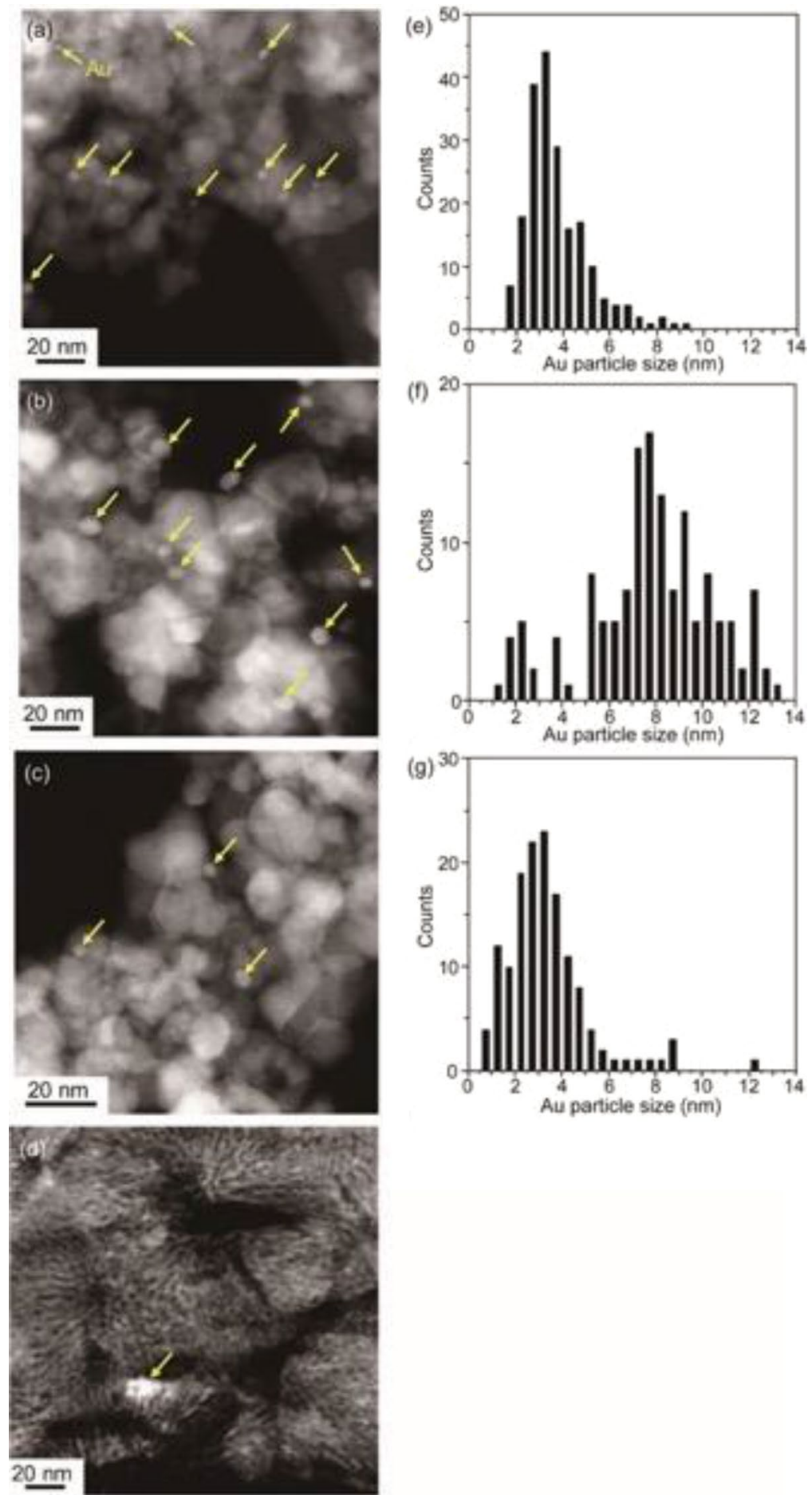

Figure 1. HAADF-STEM images of Au3/TiO $(\mathbf{a}), \mathrm{Au} 8 / \mathrm{TiO}_{2}(\mathbf{b}), \mathrm{Au} / \mathrm{ZrO}_{2}(\mathbf{c}), \mathrm{Au} / \mathrm{CeO}_{2}(\mathbf{d})$ and their size distributions of $\mathrm{Au}$ nanoparticles for $\mathrm{Au} 3 / \mathrm{TiO}_{2}(\mathbf{e}), \mathrm{Au} 8 / \mathrm{TiO}_{2}(\mathbf{f})$, and $\mathrm{Au} / \mathrm{ZrO}_{2}(\mathbf{g})$. Au nanoparticles were observed as brighter spots and yellow arrows indicate the Au nanoparticles. Only small amount of large Au aggregates was found in $\mathrm{Au} / \mathrm{CeO}_{2}$.

Effects of $\mathrm{Au} / \mathrm{ZrO}_{2}$ and $\mathrm{Au} / \mathrm{CeO}_{2} \mathrm{NPs}$ on LPS-induced inflammation. After showing the antiinflammatory effect of $\mathrm{Au} / \mathrm{TiO}_{2} \mathrm{NPs}$, we investigated if this effect was related to the chemical nature of the $\mathrm{MOx}$ NPs. To answer this question, we examined the effect of Au NPs deposited on either $\mathrm{ZrO}_{2}$ or $\mathrm{CeO}_{2} \mathrm{NPs}$ on mouse peritoneal macrophages. Physicochemical characterization of these Au/MOx are provided in Table 1. No effect of these NPs on macrophages viability was observed (Fig. 3). 
a

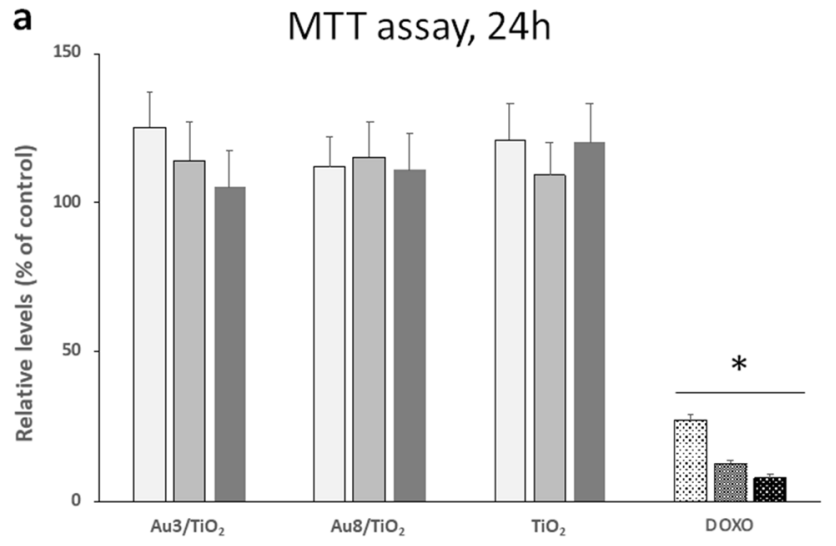

C

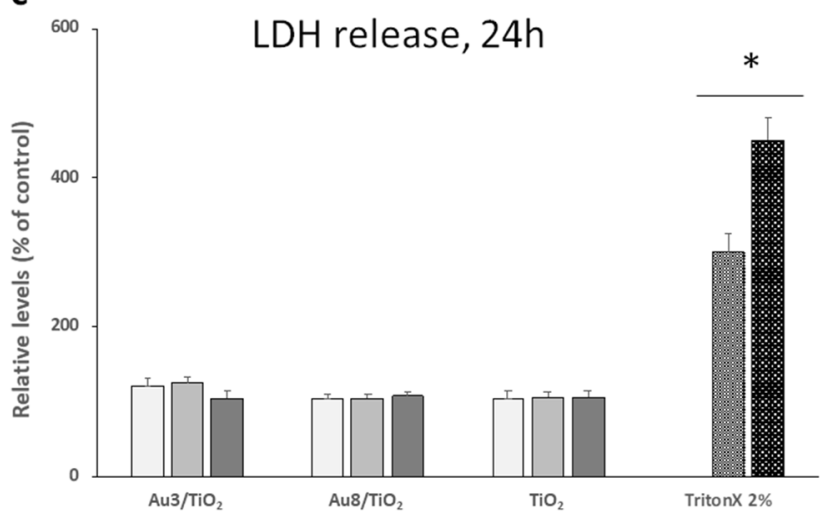

b

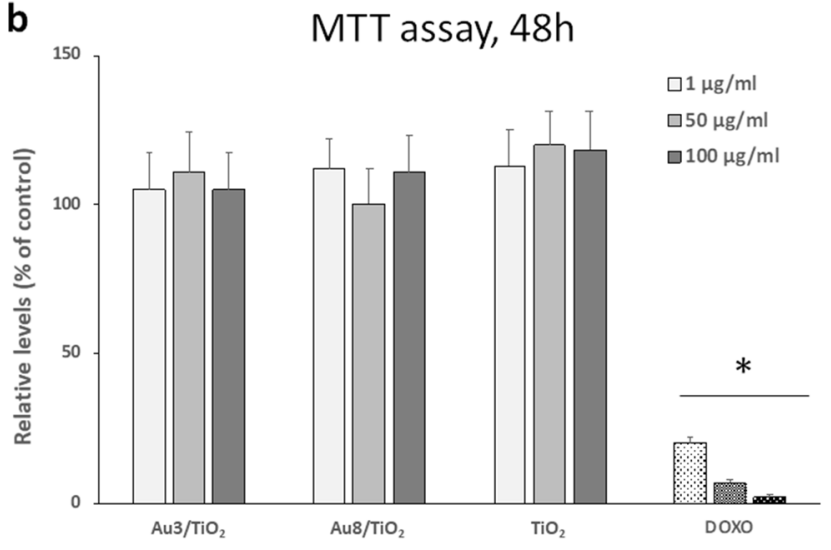

d

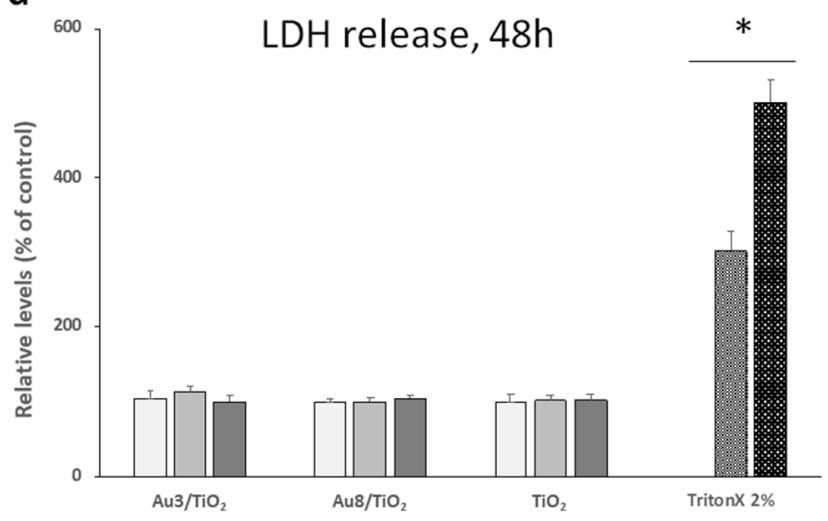

Figure 2. Cytotoxicity of Au nanoparticles (NPs) with two different diameters ( 3 and $8 \mathrm{~nm}$ respectively) supported on pristine $\mathrm{TiO}_{2}\left(\mathrm{Au} 3 / \mathrm{TiO}_{2}\right.$ and $\mathrm{Au} 8 / \mathrm{TiO}_{2}$ respectively) and $\mathrm{TiO}_{2} \mathrm{NPs}$ alone on mouse peritoneal macrophages. Cell viability was measured using the MTT assay $(\mathbf{a}, \mathbf{b})$ and LDH relargage $(\mathbf{c}, \mathbf{d})$ after 24 and $48 \mathrm{~h}$ incubation (panels $a$ and $c$, and b and d, respectively). Data are expressed as percentage of control condition (without NPs, $100 \%$ is the reference value) and are represented as mean \pm standard error of the mean (SEM) of 6 independent experiments. Positive controls are doxorubicine (DOXO, 1,5 and $10 \mu \mathrm{g} \mathrm{ml}^{-1}$ ) and TritonX-100 (10 vol. \%). * significantly different from control $(p<0.05)$.

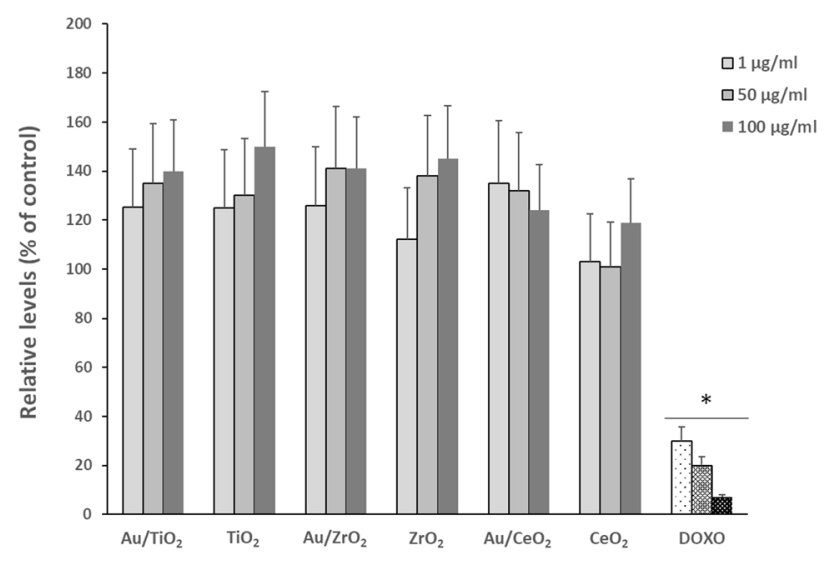

Figure 3. Cytotoxicity of Au nanoparticles (NPs) supported on $\mathrm{TiO}_{2}, \mathrm{ZrO}_{2}$ and $\mathrm{CeO}_{2} \mathrm{NPs}$ and $\mathrm{TiO}_{2}, \mathrm{ZrO}_{2}$ and $\mathrm{CeO}_{2} \mathrm{NPs}$ alone on mouse peritoneal macrophages. Cell viability was measured using the WST-1 assay after $24 \mathrm{~h}$ incubation. Data are expressed as percentage of control condition (without NPs, $100 \%$ is the reference value) and are represented as mean \pm SEM of 6 independent experiments. Positive control is doxorubicine (DOXO, 1,5 and $\left.10 \mu \mathrm{g} \mathrm{ml}^{-1}\right)^{\star}$ significantly different from control $(p<0.05)$. 


\begin{tabular}{|l|l|l|}
\hline Nanoparticle & Mean values \pm SEM & Statistical significance \\
\hline $\mathrm{Au} / \mathrm{TiO}_{2}$ & $12,068 \pm 499$ & $*$ \\
\hline $\mathrm{TiO}_{2}$ & $13,547 \pm 340$ & \\
\hline $\mathrm{Au} / \mathrm{ZrO}_{2}$ & $9170 \pm 109$ & $* *$ \\
\hline $\mathrm{ZrO}$ & $13,538 \pm 129$ & \\
\hline $\mathrm{Au} / \mathrm{CeO}_{2}$ & $12,743 \pm 340$ & \\
\hline $\mathrm{CeO}_{2}$ & $12,583 \pm 255$ & $\#$ \\
\hline
\end{tabular}

Table 2. Reactive oxygen species (ROS) production in RAW 264.7 cells after expositions to different NPs. The final concentration of NPs was $50 \mu \mathrm{g} \mathrm{ml}^{-1}$. Amounts of ROS production were evaluated by the DCFH-DA $(\mathrm{n}=7) .{ }^{*} p<0.05$ vs $\mathrm{TiO}_{2},{ }^{* *} p<0.01$ vs $\mathrm{ZrO}_{2},{ }^{*} p<0.05$ vs $\mathrm{TiO}_{2}$ and $\mathrm{ZrO}_{2}$.

Concerning LPS-induced inflammation, no effect was observed with $\mathrm{Au} / \mathrm{CeO}_{2} \mathrm{NPs}$, whereas $\mathrm{Au} / \mathrm{ZrO} \mathrm{NPs}_{2}$ attenuated LPS-induced IL- $1 \beta$ production without any effect on TNF- $\alpha$ concentration (Fig. $5 \mathrm{a}, \mathrm{b}$ ). Therefore, we can conclude that $\mathrm{Au} / \mathrm{MOx}$ possess an anti-inflammatory effect which depends on the nature of the MOx NPs and on the inflammatory mediator examined.

Is the anti-inflammatory effect of Au/MOx NP related to cytokines adsorption on their surface? We investigated the mechanisms underlying the anti-inflammatory effect of Au/MOx. Since MOx NPs adsorb different proteins on their surfaces ${ }^{9}$, we then investigated if the decreased concentration of LPS-induced TNF- $\alpha$ and IL- $1 \beta$ concentration observed with $\mathrm{Au} / \mathrm{TiO}_{2}$ and $\mathrm{Au} / \mathrm{ZrO}_{2}$ (only for IL- $1 \beta$ in this last case) was related to adsorption of these cytokines on these $\mathrm{Au} / \mathrm{MOx}$. The results of these experiments showed that incubation of each cytokine with the different $\mathrm{Au} / \mathrm{MOx}$ did not change its respective concentration when compared to the MOx NPs without $\mathrm{Au}$ (Fig. 6). This result excludes cytokines adsorption as a mechanism explaining the anti-inflammatory effect of $\mathrm{Au} / \mathrm{TiO}_{2}$ and $\mathrm{Au} / \mathrm{ZrO}_{2}$.

Is the anti-inflammatory effect of Au/MOx related to their antioxidant properties? We then examined if the anti-inflammatory effect of $\mathrm{Au} / \mathrm{TiO}_{2}$ and $\mathrm{Au} / \mathrm{ZrO}_{2}$ was related to antioxidant properties, as demonstrated in other conditions $s^{10,11}$. To investigate this issue, we measured the effect of $\mathrm{Au} / \mathrm{MOx}$ NPs on intracellular reactive oxygen species (ROS) concentration. These experiments showed that intracellular ROS production induced by $\mathrm{Au} / \mathrm{TiO}_{2}$ and $\mathrm{Au} / \mathrm{ZrO}_{2} \mathrm{NPs}$ was smaller than that of $\mathrm{TiO}_{2}$ and $\mathrm{ZrO}_{2}$ respectively, demonstrating an antioxidant effect of $\mathrm{Au} / \mathrm{TiO}_{2}$ and $\mathrm{Au} / \mathrm{ZrO}_{2}$ (Table 2), in accordance with their (partial) anti-inflammatory effect. This effect was more pronounced in the case of $\mathrm{Au} / \mathrm{ZrO}_{2}$ compared to $\mathrm{Au} / \mathrm{TiO}_{2}$ (mean reduction of $32 \%$ vs $11 \%$ compared to $\mathrm{ZrO}_{2}$ and $\mathrm{TiO}_{2}$ respectively). This antioxidant effect could be involved in the anti-inflammatory effect described previously. Interestingly, the level of ROS in cells exposed to $\mathrm{CeO}_{2}$ was lower as compared to those in cells exposed to $\mathrm{TiO}_{2}$ and $\mathrm{ZrO}_{2}$, which is in accordance with antioxidant properties of $\mathrm{CeO}_{2}$ described previously ${ }^{12}$. Since the pristine $\mathrm{CeO}_{2} \mathrm{NPs}$ possess antioxidant properties, the effect of Au deposited on $\mathrm{CeO}_{2}$ was probably limited.

\section{Discussion}

The most important result of this study is an anti-inflammatory effect of $\mathrm{Au} / \mathrm{MOx}$ NPs depending on the MOx nature with particle internalization but no alteration of cell viability or phagocytic capacity of Au/MOx NPs as compared to MOx NPs (Figs. 2 and 3). The effect of $\mathrm{Au} / \mathrm{TiO}_{2} \mathrm{NPs}$ was not related to Au NPs size (at least in the case of $\mathrm{Au} / \mathrm{TiO}_{2} \mathrm{NPs}$ in the range of 3-8 nm) (Fig. 4) and was dependent on the MOx NPs chemical nature $\left(\mathrm{Au} / \mathrm{TiO} \mathrm{O}_{2}>\mathrm{Au} / \mathrm{ZrO}_{2}>\mathrm{Au} / \mathrm{CeO}_{2}\right.$ if we consider the number of cytokines whose concentration was reduced by the NPs) and on the inflammatory mediator considered (Fig. 5). To the best of our knowledge, this is the first demonstration that $\mathrm{Au} / \mathrm{MOx}$ presents anti-inflammatory properties.

The effect of $\mathrm{Au} / \mathrm{MOx}$ could be related to anti-inflammatory properties of Au NPs per se. Indeed, gold colloids have been thought to cure various diseases for many centuries, and recent studies have demonstrated that this effect is mediated by inhibition of NF- $\kappa B$ activation ${ }^{13}$. Different studies showed a similar effect in the case of Au NPs in vitro and in vivo, this effect being usually mediated by antioxidant properties ${ }^{14-16}$. However, other studies showed opposite results. For example, $\mathrm{Ng}$ et al. ${ }^{16}$ showed that incubation of human bronchial epithelial cells with $50 \mu \mathrm{g} \mathrm{ml}^{-1}$ of $20 \mathrm{~nm}$ Au NPs activated NF- $\kappa B$ in bronchial epithelial cells. Close results were shown in other cell types ${ }^{17,18}$. Therefore, an anti-inflammatory effect of Au NPs per se seems not a univocal mechanism explaining the anti-inflammatory effect of Au/MOx NPs. Moreover, most of the studies showing the effect of $\mathrm{Au}$ NPs on inflammation have been conducted at much higher concentrations than the cells were exposed to in this study. Considering that Au NPs account for only $1 \%$ of the mass of Au/MOx, simply attributing the present results to the biological activity of Au NPs is unlikely.

Adsorption of TNF- $\alpha$ and IL- $1 \beta$ on Au/MOx surface could also explain their different anti-inflammatory activity. Indeed, NPs, including Au NPs, can adsorb different molecules on their surface, resulting in their inactivation and reduction in their concentration in the medium ${ }^{19}$. However, this mechanism seems unlikely in the present study, since we did not observe any significant difference in TNF- $\alpha$ and IL-1 $\beta$ levels when these cytokines were incubated with $\mathrm{TiO}_{2}$ or $\mathrm{ZrO}_{2} \mathrm{NPs}$ and their respective Au counterparts (Fig. 6).

Finally, the differences in the anti-inflammatory effect of Au/MOx NPs could be related to their different antioxidant properties. However, the anti-inflammatory effect of $\mathrm{Au} / \mathrm{MOx}$ NPs was not good consistent with the 
a

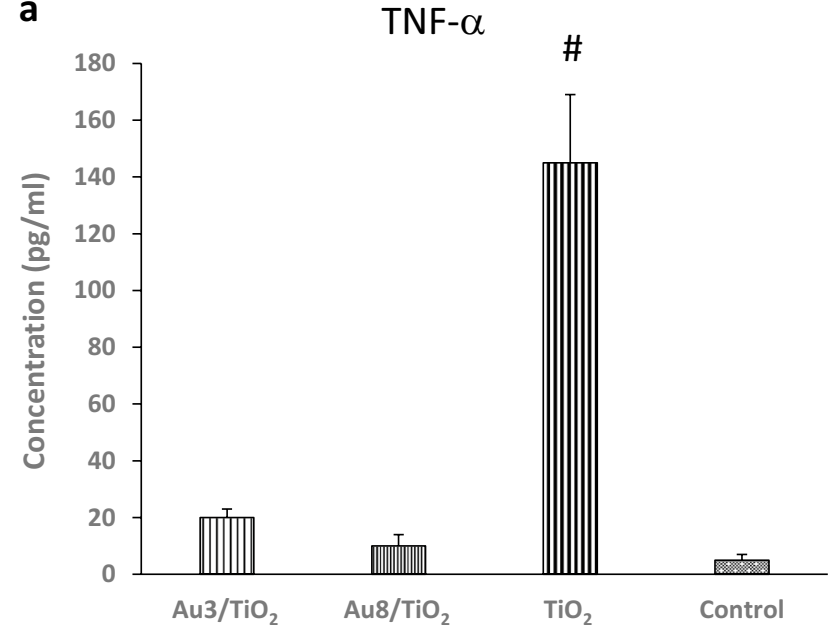

b

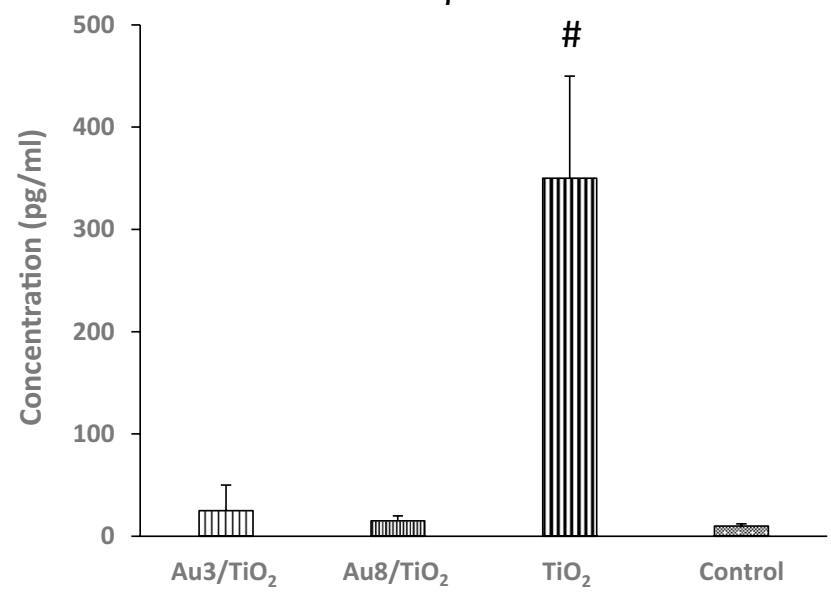

Figure 4. Effect of $\mathrm{Au} 3 / \mathrm{TiO}_{2}, \mathrm{Au} 8 / \mathrm{TiO}_{2}$ and $\mathrm{TiO}_{2} \mathrm{NPs}\left(50 \mu \mathrm{g} \mathrm{ml}^{-1}, 6 \mathrm{~h}\right.$ incubation $)$ on TNF- $\alpha$ and IL- $1 \beta$ secretion by mouse peritoneal macrophages $(\mathbf{a}, \mathbf{b})$. Data are expressed as picograms $/ \mathrm{ml}$ in cell culture medium and are represented as mean \pm SEM of 6 independent experiments. "Significantly different from control $(p<0.01)$.

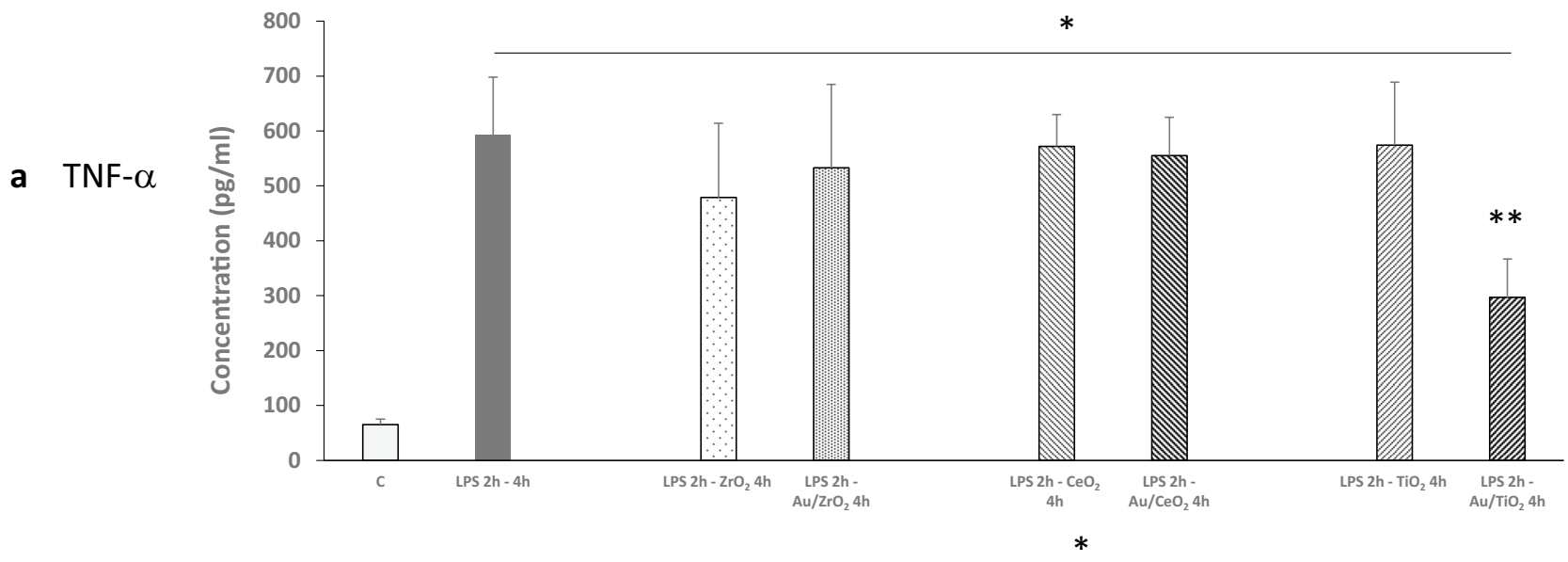

b IL-1 $\beta$

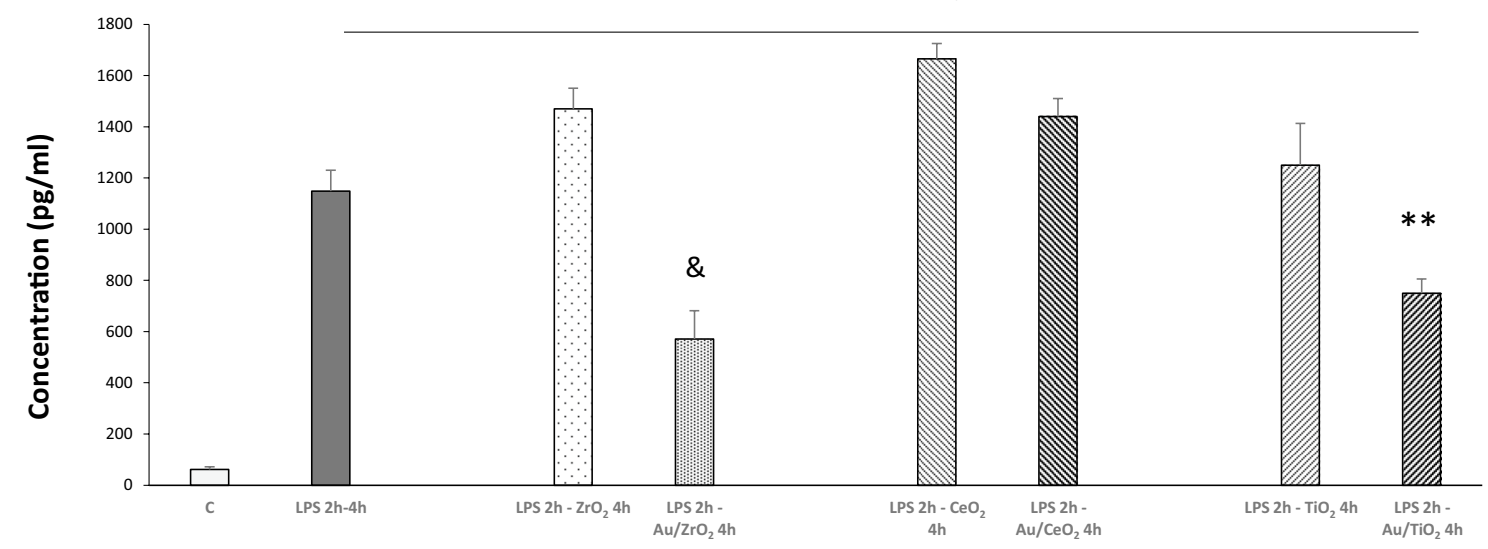

Figure 5. Effect of Au deposited on different metal oxide NPs on LPS induced TNF- $\alpha$ and IL- $1 \beta$ secretion by mouse peritoneal macrophages $(\mathbf{a}, \mathbf{b})$. Cells were incubated with culture media for $6 \mathrm{~h}$ (control condition, $\mathrm{C})$ or LPS for $2 \mathrm{~h}$, and then the following $4 \mathrm{~h}$ with LPS alone or LPS plus the different MOx or Au/MOx NPs $\left(50 \mu \mathrm{g} \mathrm{ml}^{-1}\right)$. ${ }^{*}$ Significantly different from C $(p<0.05)$, ** significantly different from LPS $2 \mathrm{~h}-\mathrm{TiO}_{2} 4 \mathrm{~h}$ $(p<0.05),{ }^{*}$ significantly different from LPS $2 \mathrm{~h}-\mathrm{ZrO}_{2} 4 \mathrm{~h}(p<0.05)$. 

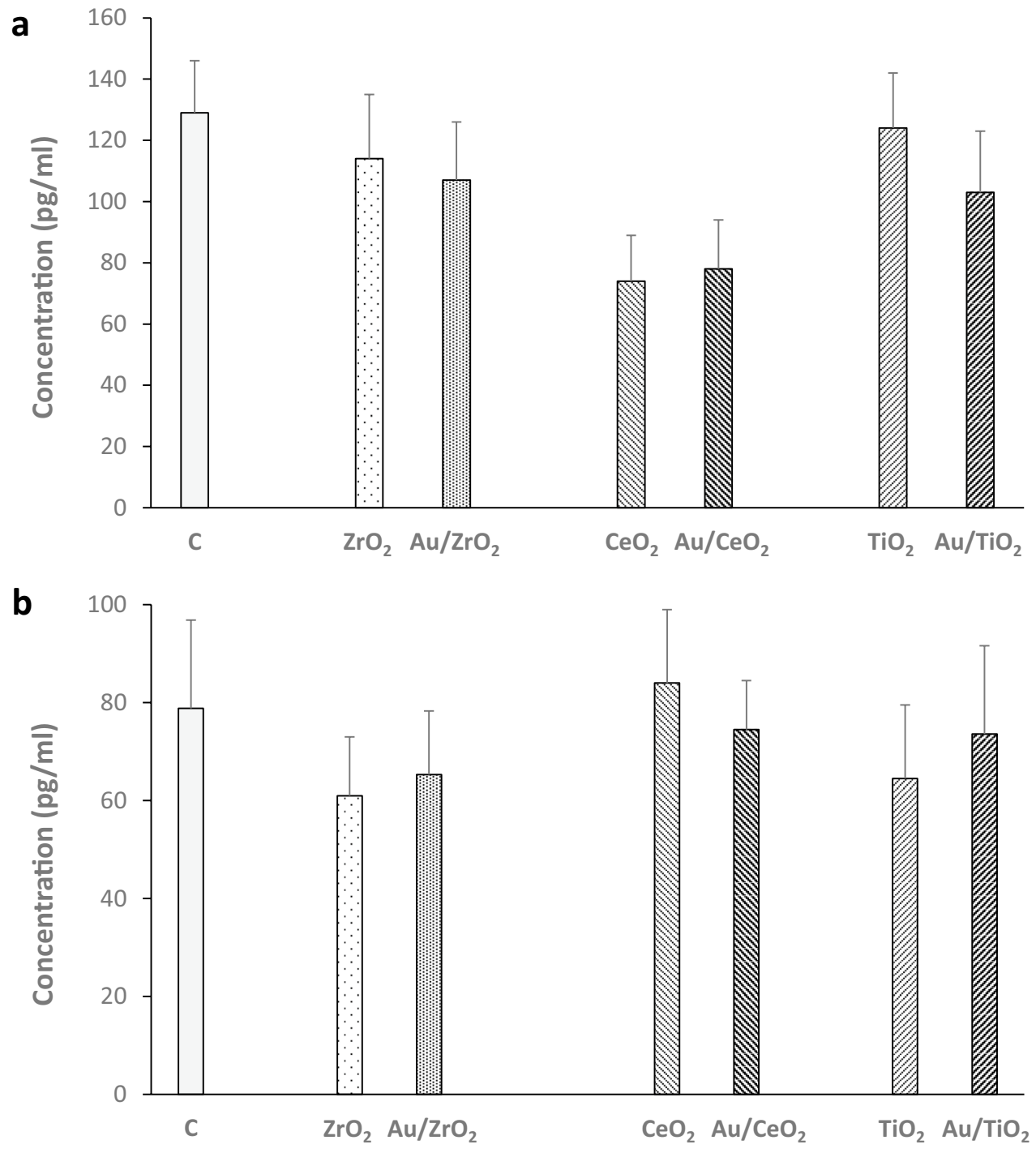

Figure 6. TNF- $\alpha$ and IL- $1 \beta$ adsorption on Au deposited on different MOx NPs. MOx or Au/MOx NPs $\left(50 \mu \mathrm{g} \mathrm{ml}^{-1}\right)$ were incubated during $6 \mathrm{~h}$ with TNF- $\alpha\left(150 \mathrm{pg} \mathrm{ml}^{-1}\right)$ and IL-1 $\beta\left(100 \mathrm{pg} \mathrm{ml}^{-1}\right)$ in culture media, then the cytokines were quantified in the media after centrifugation.

intracellular antioxidant properties, since both $\mathrm{Au} / \mathrm{TiO}$ and $\mathrm{Au} / \mathrm{ZrO}_{2} \mathrm{NPs}$ reduced intracellular ROS concentration whereas only $\mathrm{Au} / \mathrm{TiO}_{2}$ attenuated both TNF- $\alpha$ and IL-1 $\beta$ induction (Fig. 5). In concordance with different studies, $\mathrm{CeO}_{2} \mathrm{NPs}$ exerted an antioxidant effect as compared to $\mathrm{TiO}_{2}$ and $\mathrm{ZrO}_{2} \mathrm{NPs}$ (Table 1), but this effect was not accompanied by an anti-inflammatory effect. On the other hand, the absence of an anti-inflammatory effect of $\mathrm{Au} / \mathrm{CeO}_{2}$ was paralleled by an absence of an antioxidant effect of $\mathrm{CeO}_{2} \mathrm{NPs}$. Collectively, these data suggest that, in contrast with our initial hypothesis, an antioxidant effect is not a mechanism globally explaining the anti-inflammatory effect of $\mathrm{Au} / \mathrm{TiO}_{2}$ and $\mathrm{Au} / \mathrm{ZrO}_{2}$. Indeed, an antioxidant effect could potentially explain the effect of $\mathrm{Au} / \mathrm{TiO}_{2} \mathrm{NPs}$ but not the one of $\mathrm{Au} / \mathrm{ZrO}_{2} \mathrm{NPs}$, because $\mathrm{Au} / \mathrm{ZrO}_{2} \mathrm{NPs}$ had showed an antioxidant effect similar to $\mathrm{Au} / \mathrm{TiO}_{2}$ but attenuated only IL- $1 \beta$ induction. Consequently, the anti-oxidant effect of $\mathrm{Au} / \mathrm{ZrO}_{2}$ appears to relate on pathways inhibiting IL- $1 \beta$ but not TNF- $\alpha$ expression.

Numerous mechanisms have been reported to control the production and activity of IL-1 $\beta$, including the processing of the $31-\mathrm{kDa}$, inactive IL- $1 \beta$ precursor into the bioactive, $17-\mathrm{kDa}$ cytokine via intracellular protein complexes termed the inflammasomes ${ }^{20}$. The most intensely studied inflammasome is the NLRP3 inflammasome. Various stimuli activate the NLRP3 inflammasome: bacterial structures such as muramyl dipeptide or LPS, bacterial RNA, $\beta$-glucan, double-stranded RNA, etc. The release of ROS has been reported to mediate NLRP3 inflammasome activation by various stimuli, including LPS, but this has been surrounded by controversy ${ }^{21}$. Other proposed mechanisms responsible for NLRP3 inflammasome activation are: (i) translocation to mitochondria ${ }^{22}$, (ii) release of mitochondrial DNA or cardiolipin ${ }^{23}$, (iii) release of lysosomal cathepsins into the cytoplasm ${ }^{24}$, and (iv) calcium-dependent phospholipase 2 activation $^{20}$. Interference with one or several mechanisms could explain attenuation of LPS-induced IL- $1 \beta$ expression by $\mathrm{Au} / \mathrm{ZrO}_{2} \mathrm{NPs}$. However, investigating these possibilities needs further studies. 
This study presents four main limitations. First, as MOx NPs are made of different materials, the cells will be exposed to a different amount of particles. However, we consider this possibility unlikely because Au content in the different Au/MOx NPs was very low (around $1 \mathrm{wt} \%$ ). Second, we used two different murine macrophages populations: primary cultures of peritoneal macrophages and the RAW 264.7 macrophages cell line. We chose to use primary cultures of peritoneal macrophages because a large body of literature combining both in vitro approaches using peritoneal macrophages, and in vivo experiments in mice, demonstrated the relevance of the findings obtained in peritoneal macrophages, and their potential translation to what may occur in vivo ${ }^{25-27}$. Moreover, we wanted to be at most in accordance with the 3R's guidelines, and for this reason we performed the experiments with the murine macrophage cell line RAW 264.7. Indeed, as demonstrated by Maurya and coworkers $^{28}$, RAW264.7 cells behave similarly to primary cultures of peritoneal macrophages cells in some ways and can be used as a good model for inflammation- and immune function-related kinetic studies. RAW 264.7 behave different from peritoneal macrophages in other aspects of lipid metabolism and phenotypes used as models for various disorders such as atherosclerosis, but these types of responses were not concerned in the present study. Third, we only measured two cytokines as a surrogate of inflammatory markers. Even if these cytokines are broadly representative of the inflammatory reaction and are one of the very early ones in the inflammatory cascade, and we investigate primary murine macrophages (a key cell involved in inflammation), a wider analysis of mediators of this reaction is necessary to validate the present results. Fourth, we investigated only three MOx NPs supports. Although we choose supports widely characterized in terms of catalytic properties when combined with Au NPs, investigating a broader panel of MOx could allow a better characterizing the anti-inflammatory properties of $\mathrm{Au} / \mathrm{MOx} \mathrm{NPs}$.

In conclusion, despite of the above-mentioned limitations, this study showed that $\mathrm{Au} / \mathrm{MOx}$ possess antiinflammatory properties in macrophages and the effect depended on the kind of $\mathrm{MOx} \mathrm{NPs}$. $\mathrm{Au} / \mathrm{TiO}{ }_{2}$ showed antiinflammatory effect for both TNF- $\alpha$ and IL- $1 \beta$. Although $\mathrm{Au} / \mathrm{ZrO}_{2}$ was ineffective to reduce the concentration of TNF- $\alpha$, the anti-inflammatory effect for IL- $1 \beta$ was more pronounced for $\mathrm{Au} / \mathrm{ZrO}_{2}$ as compared to $\mathrm{Au} / \mathrm{TiO} \mathrm{O}_{2}$. In addition, $\mathrm{Au} / \mathrm{TiO}_{2}$ and $\mathrm{Au} / \mathrm{ZrO}_{2}$ exhibited improved antioxidant properties in RAW 264.7 compared to the pristine $\mathrm{TiO}_{2}$ and $\mathrm{ZrO}_{2} \mathrm{NPs}$. Although the relationships between antioxidant properties and anti-inflammatory effect of Au/MOx NPs and the mechanism are still unclear, our finding, anti-inflammatory effect of Au/MOx NPs could have potential applications in the clinical setting, since it does not interfere with physiological parameters of these cells such as viability and phagocytosis.

\section{Methods}

Preparation of Au nanoparticles supported on metal oxides (Au/MOx). Materials. $\mathrm{TiO}_{2}(\mathrm{AER}-$ OXIDE P25) was supplied from Nippon Aerosil Co., Ltd. $\mathrm{ZrO}_{2}$ (RC-100) and $\mathrm{CeO}_{2}$ (high purity fine cerium oxide) were purchased from Daiichi Kigenso Kagaku Kogyo Co., Ltd. Tetrachloroauric acid $\left(\mathrm{HAuCl}_{4} \cdot 4 \mathrm{H}_{2} \mathrm{O}\right)$ and dimethyl gold(III)(acetylacetonate), $\mathrm{Me}_{2} \mathrm{Au}(\mathrm{acac})$, were purchased from Tanaka Kikinzoku Kogyo K.K. and Tri Chemical Laboratories Inc., respectively. $\mathrm{Au} / \mathrm{ZrO}_{2}$ and $\mathrm{Au} / \mathrm{CeO}_{2}$ prepared by deposition-precipitation were purchased from Haruta Gold Inc. All reagents and materials were used as received.

Characterization of Au/MOx. Average particle size of metal oxides after the deposition of Au NPs were measured by laser diffraction/scattering particle size distribution analyzer using a HORIBA, Partica LA-950V2. Specific surface area of metal oxides was estimated from the $\mathrm{N}_{2}$ adsorption measurement was carried out using a SHIMADZU, Tristar 3000 . The samples were pretreated at $200{ }^{\circ} \mathrm{C}$ for $2 \mathrm{~h}$ under vacuum, and then the $\mathrm{N}_{2}$ adsorption isotherms were obtained at $-196^{\circ} \mathrm{C}$. The Brunauer-Emmet-Teller (BET) method was used to calculate the specific surface area. Loading amount of Au on metal oxides were measured by inductively coupled plasma atomic emission spectroscopy (ICP-AES, Thermo Fisher Scientific, iCAP6500) or atomic absorption spectrometry (AAS, SHIMADZU, AA-6200). The samples were treated in aqua regia to dissolve Au NPs, filtered, and then diluted to measure. Average size of Au NPs supported on metal oxides were estimated by high-angle annular dark-field scanning transmission electron microscopic (HAADF-STEM) observation using a JEOL, JEM-3200FS.

Preparation of Au/MOx. Au NPs with two different mean diameters ( 3 and $8 \mathrm{~nm}$ ) supported on pristine $\mathrm{TiO}_{2}$ NPs were prepared, termed $\mathrm{Au} 3 / \mathrm{TiO}_{2}$ and $\mathrm{Au} 8 / \mathrm{TiO}_{2}$, respectively. $\mathrm{Au} 3 / \mathrm{TiO}_{2}$ was prepared by deposition-precipitation ${ }^{3}$. An aqueous solution of $\mathrm{HAuCl}_{4}(1 \mathrm{mM}, 50 \mathrm{~mL})$ was warmed to $70{ }^{\circ} \mathrm{C}$, and the $\mathrm{pH}$ was adjusted to 6 by adding $\mathrm{NaOH}$ aqueous solution. $\mathrm{TiO}_{2}(1.0 \mathrm{~g})$ was added to the solution and the suspension was stirred at $70{ }^{\circ} \mathrm{C}$ for $1 \mathrm{~h}$. The suspension was centrifuged, washed with water at $40^{\circ} \mathrm{C}$ for five times, and then filtered. The resultant powder was dried in air at $100{ }^{\circ} \mathrm{C}$ overnight and calcined at $300^{\circ} \mathrm{C}$ for $4 \mathrm{~h}$ to reduce $\mathrm{Au}(\mathrm{III})$ to $\mathrm{Au}(0)$. $\mathrm{Au} / \mathrm{ZrO}_{2}$ and $\mathrm{Au} / \mathrm{CeO}_{2}$ were also prepared by deposition-precipitation as well as $\mathrm{Au} 3 / \mathrm{TiO} \mathrm{O}_{2}$. Au8/TiO $\mathrm{T}_{2}$ was prepared by solid grinding ${ }^{5}$. $\mathrm{TiO}_{2}(1.0 \mathrm{~g})$ and $\mathrm{Me}_{2} \mathrm{Au}(\mathrm{acac})(15 \mathrm{mg})$ were ground in an agate mortar in air at room temperature for $20 \mathrm{~min}$. The mixture was calcined at $300{ }^{\circ} \mathrm{C}$ for $2 \mathrm{~h}$ to give $\mathrm{Au} 8 / \mathrm{TiO}_{2}$.

Physicochemical properties of the obtained $\mathrm{Au} / \mathrm{MOx}$ are summarized in Table 1 . The primary particle sizes of $\mathrm{Au} / \mathrm{TiO}_{2}, \mathrm{Au} / \mathrm{ZrO}_{2}$, and $\mathrm{Au} / \mathrm{CeO}_{2}$ were $26 \mathrm{~nm}, 11 \mathrm{~nm}$, and $7.3 \mathrm{~nm}$ respectively, estimated from their specific surface areas of the MOx NPs. The secondary particle sizes of $\mathrm{Au} / \mathrm{TiO}_{2}, \mathrm{Au} / \mathrm{ZrO}$, and $\mathrm{Au} / \mathrm{CeO}_{2}$ were $9.4 \mu \mathrm{m}$, $3.6 \mu \mathrm{m}$, and $2.4 \mu \mathrm{m}$, respectively, determined by light scattering. The actual Au loadings for $\mathrm{Au} 3 / \mathrm{TiO}_{2}, \mathrm{Au} 8 /$ $\mathrm{TiO}_{2}, \mathrm{Au} / \mathrm{ZrO}_{2}$, and $\mathrm{Au} / \mathrm{CeO}_{2}$ were $0.96,1.18,0.97$, and $0.96 \mathrm{wt} \%$, respectively. The mean diameters of Au NPs were estimated by HAADF-STEM observation to be $3.3 \pm 1.4 \mathrm{~nm}$ for Au3/ $\mathrm{TiO}_{2}, 7.8 \pm 2.7 \mathrm{~nm}$ for $\mathrm{Au} 8 / \mathrm{TiO}_{2}$, and $3.3 \pm 1.8 \mathrm{~nm}$ for $\mathrm{Au} / \mathrm{ZrO}_{2}$ (Fig. 1). In the case of $\mathrm{Au} / \mathrm{CeO}_{2}$, it was difficult to observe Au NPs because Au was mostly deposited as single atoms and the atomic number of Ce is close to that of $\mathrm{Au}$. 
The different NPs were evaluated for LPS contamination (Limulus Amebocyte Lysate test), and the observed absorbance at $405 \mathrm{~nm}$ was below detection limits demonstrating no LPS contamination.

Cells isolation and incubation with nanoparticles. Peritoneal macrophages and macrophages from the RAW 264.7 cell line were used in the different experiments.

Mice peritoneal macrophages were prepared as follows. C57BL/6 mice were injected intraperitoneally with $1 \mathrm{ml}$ of 3\% Brewer thioglycollate (Sigma-Aldrich, B2551). After $96 \mathrm{~h}$, peritoneal cells were harvested by lavage with $0.67 \%$ phosphate buffered saline (PBS). After a soft centrifugation, cells were maintained in Dulbecco's modified Eagle medium (DMEM) $4.5 \mathrm{~g} \mathrm{l}^{-1}$ glucose supplemented with $10 \%$ fetal calf serum (FCS)and $1 \%$ penicillin and $1 \%$ streptomycin. Then mice peritoneal macrophagic cells were exposed for 6-48 $\mathrm{h}$ to $1-100 \mu \mathrm{g} \mathrm{ml}$ particles of $\mathrm{Au} / \mathrm{TiO}_{2}, \mathrm{Au} / \mathrm{ZrO}_{2}, \mathrm{Au} / \mathrm{CeO}_{2}$, and $\mathrm{MOx}$ alone.

The RAW 264.7 cells were cultured using a medium having the same composition as above.

Nanoparticle interference with the signal was tested in all of the colorimetric assays. No interference was observed.

Cellular viability. The viability of cells was measured by 3-[4,5-dimethylthiazol-2-yl]-2,5 diphenyl tetrazolium bromide (MTT) assay, 2-(4-iodophenyl)-3-(4-nitrophenyl)-5-(2,4-disulfophenyl)-2H-tetrazolium, monosodium salt (WST-1) assay, and the quantification of the release of lactate dehydrogenase (LDH).

Inflammatory responses. Inflammatory response was evaluated by the quantification of cytokines such as tumor necrosis factor (TNF)- $\alpha$ and interleukin (IL)- $1 \beta$ in cell supernatant, measured by enzyme-linked immunosorbent assay (ELISA).

Measurement of oxidative stress by DCFH-DA assay. Endogenous ROS were quantified by oxidation of 2',7'-dichlorofluorescin diacetate (DCFH-DA) into 2',7'-dichlorofluorescin (Sigma, Saint Quentin Fallavier, France). Briefly, cells were cultivated in six-well culture plates and treated with $50 \mu \mathrm{g} \mathrm{ml}^{-1} \mathrm{NPs}$. Cells were also treated with $250 \mu \mathrm{M} \mathrm{H}_{2} \mathrm{O}_{2}$ as a positive control (data not shown). Cells were incubated with $20 \mu \mathrm{M}$ $\mathrm{DCFH}-\mathrm{DA}$ for $30 \mathrm{~min}$ at $37^{\circ} \mathrm{C}$ and fluorescence recorded for $90 \mathrm{~min}$. Results were expressed as the mean ratio of fluorescence recorded every $15 \mathrm{~min}$ during the $90 \mathrm{~min}$ period.

Measurement of TNF- $\alpha$ and IL-1 $\beta$ adsorption to NPs. Adsorption of TNF- $\alpha$ and IL- $1 \beta$ adsorption to NPs was performed by ELISA as described previously described ${ }^{29}$.

Statistical analysis. JASP software (version 0.11.1, https://jasp-stats.org/) was used to analyze quantitative data. Non-parametric ANOVA was used to compare multiple groups. Paired comparisons with Mann-Whitney test were performed if the differences using ANOVA were statistically significantly different. Data were presented as mean values \pm standard error of the mean (SEM), and results were considered statistically significant if $p<0.05$.

Study approval for animal experiments. The Institutional Animal Care and Use Committee approved experimental procedures on mice (APAFIS authorization \#14914-2018042515599016).

All methods were carried out in accordance with relevant guidelines and regulations and are reported in accordance with ARRIVE guidelines for the reporting of animal experiments.

\section{Data availability}

The datasets used and/or analyzed during the current study are available from the corresponding author on reasonable request.

Received: 12 February 2021; Accepted: 2 November 2021

Published online: 30 November 2021

\section{References}

1. Haruta, M. When gold is not noble: Catalysis by nanoparticles. Chem. Rec. 3(2), 75-87 (2003).

2. Taketoshi, A. \& Haruta, M. Size- and structure-specificity in catalysis by gold clusters. Chem. Lett. 43, 380-387. https://doi.org/ $10.1246 / \mathrm{cl} .131232(2014)$.

3. Haruta, M. et al. Low-temperature oxidation of Co over gold supported on Tio2, AlphaFe2o3, and Co3o4. J. Catal. 144, 175-192. https://doi.org/10.1006/jcat.1993.1322 (1993).

4. Ishida, T., Murayama, T., Taketoshi, A. \& Haruta, M. Importance of size and contact structure of gold nanoparticles for the genesis of unique catalytic processes. Chem. Rev. 120(2), 464-525 (2020).

5. Ishida, T. et al. Influence of the support and the size of gold clusters on catalytic activity for glucose oxidation. Angew. Chem. Int. Ed. 47(48), 9265-9268 (2008).

6. Ishida, T. \& Haruta, M. Gold catalysts: Towards sustainable chemistry. Angew. Chem. Int. Ed. 46(38), 7154-7156 (2007).

7. Menchón, C. et al. Gold nanoparticles supported on nanoparticulate ceria as a powerful agent against intracellular oxidative stress. Small Weinh Bergstr Ger. 8(12), 1895-1903 (2012).

8. Tuder, R. M., Davis, L. A. \& Graham, B. B. Targeting energetic metabolism: A new frontier in the pathogenesis and treatment of pulmonary hypertension. Am. J. Respir. Crit. Care Med. 185(3), 260-266 (2012).

9. Lundqvist, M. et al. Nanoparticle size and surface properties determine the protein corona with possible implications for biological impacts. Proc. Natl. Acad. Sci. U S A. 105(38), 14265-14270 (2008).

10. Lucchetti, B. F. C. et al. Metabolic syndrome agravates cardiovascular, oxidative and inflammatory dysfunction during the acute phase of Trypanosoma cruzi infection in mice. Sci. Rep. 9(1), 18885 (2019). 
11. Scalavino, V. et al. miR-369-3p modulates inducible nitric oxide synthase and is involved in regulation of chronic inflammatory response. Sci. Rep. 10(1), $15942(2020)$.

12. Pezzini, I. et al. Cerium oxide nanoparticles: The regenerative redox machine in bioenergetic imbalance. Nanomedicine 12(4), $403-416$ (2017).

13. Narayanan, K. B. \& Park, H. H. Pleiotropic functions of antioxidant nanoparticles for longevity and medicine. Adv. Colloid Interface Sci. 201-202, 30-42 (2013).

14. Zhu, S. et al. Orally administered gold nanoparticles protect against colitis by attenuating Toll-like receptor 4- and reactive oxygen/ nitrogen species-mediated inflammatory responses but could induce gut dysbiosis in mice. J. Nanobiotechnol. 16(1), 86 (2018).

15. Pereira, D. V. et al. Effects of gold nanoparticles on endotoxin-induced uveitis in rats. Invest. Ophthalmol. Vis. Sci. 53(13), 8036-8041 (2012).

16. Haupenthal, D. P. D. S. et al. Effects of chronic treatment with gold nanoparticles on inflammatory responses and oxidative stress in Mdx mice. J. Drug Target. 28(1), 46-54 (2020).

17. Khan, H. A., Abdelhalim, M. K., Alhomida, A. S. \& Al Ayed, M. S. Transient increase in IL-1 $\beta$, IL-6 and TNF- $\alpha$ gene expression in rat liver exposed to gold nanoparticles. Genet. Mol. Res. GMR 12(4), 5851-5857 (2013).

18. Li, Y. et al. Bacterial endotoxin (lipopolysaccharide) binds to the surface of gold nanoparticles, interferes with biocorona formation and induces human monocyte inflammatory activation. Nanotoxicology 11(9-10), 1157-1175 (2017).

19. Mukherjee, P. et al. Antiangiogenic properties of gold nanoparticles. Clin. Cancer Res. 11(9), 3530-3534 (2005).

20. Lamkanfi, M. \& Dixit, V. M. Mechanisms and functions of inflammasomes. Cell 157(5), 1013-1022 (2014).

21. Netea, M. G., van de Veerdonk, F. L., van der Meer, J. W. M., Dinarello, C. A. \& Joosten, L. A. B. Inflammasome-independent regulation of IL-1-family cytokines. Annu. Rev. Immunol. 33, 49-77 (2015).

22. Subramanian, N., Natarajan, K., Clatworthy, M. R., Wang, Z. \& Germain, R. N. The adaptor MAVS promotes NLRP3 mitochondrial localization and inflammasome activation. Cell 153(2), 348-361 (2013).

23. Nakahira, K. et al. Autophagy proteins regulate innate immune responses by inhibiting the release of mitochondrial DNA mediated by the NALP3 inflammasome. Nat. Immunol. 12(3), 222-230 (2011).

24. Duewell, P. et al. NLRP3 inflammasomes are required for atherogenesis and activated by cholesterol crystals. Nature 464(7293), 1357-1361 (2010).

25. Tabet, L. et al. Coating carbon nanotubes with a polystyrene-based polymer protects against pulmonary toxicity. Part Fibre Toxicol. 21(8), 3 (2011).

26. Hevia, H. et al. 5'-methylthioadenosine modulates the inflammatory response to endotoxin in mice and in rat hepatocytes. Hepatology 39(4), 1088-1098 (2004).

27. Bachoual, R. et al. Biological effects of particles from the paris subway system. Chem. Res. Toxicol. 20(10), 1426-1433 (2007).

28. Maurya, M. R. et al. Analysis of inflammatory and lipid metabolic networks across RAW264.7 and thioglycolate-elicited macrophages. J. Lipid Res. 54(9), 2525-2542 (2013).

29. Bussy, C. et al. Critical role of surface chemical modifications induced by length shortening on multi-walled carbon nanotubesinduced toxicity. Part Fibre Toxicol. 9, 46 (2012).

\section{Acknowledgements}

This work is financially supported by JSPS KAKENHI Grant Number JP19K15410.

\section{Author contributions}

T.F. prepared and analyzed NPs, performed chemical experiments and critically reviewed the manuscript. T.F., M.Z. and D.E. performed biological experiments. T.M., M.H., and S.L. critically reviewed the manuscript and worked on its final elaboration. T.I. contributed to the design of the study, critically reviewed the manuscript and worked on its final elaboration. J.B. designed the study and wrote the first and final drafts of the manuscript. All authors approved the final version of the manuscript.

\section{Competing interests}

The authors declare no competing interests.

\section{Additional information}

Supplementary Information The online version contains supplementary material available at https://doi.org/ 10.1038/s41598-021-02419-4.

Correspondence and requests for materials should be addressed to T.F. or J.B.

Reprints and permissions information is available at www.nature.com/reprints.

Publisher's note Springer Nature remains neutral with regard to jurisdictional claims in published maps and institutional affiliations.

(i) Open Access This article is licensed under a Creative Commons Attribution 4.0 International License, which permits use, sharing, adaptation, distribution and reproduction in any medium or format, as long as you give appropriate credit to the original author(s) and the source, provide a link to the Creative Commons licence, and indicate if changes were made. The images or other third party material in this article are included in the article's Creative Commons licence, unless indicated otherwise in a credit line to the material. If material is not included in the article's Creative Commons licence and your intended use is not permitted by statutory regulation or exceeds the permitted use, you will need to obtain permission directly from the copyright holder. To view a copy of this licence, visit http://creativecommons.org/licenses/by/4.0/.

(c) The Author(s) 2021 